\title{
Factors affecting the direction of growth of tree roots
}

\author{
M.P. Coutts
}

Forestry Commission, Northern Research Station, Roslin, Midlothian, EH25 9SY, Scotland, U.K.

\section{Introduction}

The direction of growth of the main roots of a tree is an important determinant of the form of the root system. It affects the way the system exploits the soil (Karizumi, 1957) and has practical significance for the design of containers and for cultivation systems which can influence tree growth and anchorage. This review discusses the way in which root orientation is established and how it is modified by the environment.

The form of tree root systems can be classified in many ways but the commonest type in boreal forests is dominated by horizontally spreading lateral roots within about $20 \mathrm{~cm}$ of the ground surface (Fayle, 1975; Strong and La Roi, 1983). A vertical taproot may persist or may disappear during development. Sinker roots are more or less vertical roots which grow down from the horizontal laterals. They are believed to be important for anchorage and for supplying water during dry periods. Roots which descend obliquely from the tap or lateral roots are also present and the distinction between these and sinkers is a matter of definition. Differences in root form could arise from differences in root direction or from differential growth and survival of roots which were originally growing in many directions. In practice, both the direction of growth and differential development contribute to the final form.

There is scant information about the principal controls over the orientation of tree roots. Most studies deal with herbaceous species, and even for them experimental work and reviews have generally been confined to geotropism of the seedling radicle. The direction sensing apparatus lies in the root cap (Wilkins, 1975). The structure of the root cap is variable, but there is no essential difference between those of herbaceous species and trees. Work on herbaceous species therefore has a strong relevance for trees, but certain differences must be noted. For example, any correlative effects between the taproot and laterals may be modified in trees by the size, age and complexity of their root systems. Furthermore, the roots of herbs, and especially of annuals, may have evolved optimal responses to seasonal conditions, whereas the young tree must build a root system to support it physically and physiologically for many years. An example of response to temporary influences is given by soybean, in which the lateral roots grow out $45 \mathrm{~cm}$ horizontally from the taproot, then turn down vertically during the summer (Raper and Barber, 1970), possibly in response to 
drought or high temperature (Mitchell and Russell, 1971). A forest tree could not survive on a root system so restricted laterally.

\section{Orthogeotropic roots}

In both herbs and trees the seedling taproot (or radicle) is usually positively geotropic. If the root is displaced from its vertical (orthogeotropic) position, the tip bends downwards. The signal for the direction of the vector of gravity is given by the sedimentation of starch grains onto the floor of statocytes in the central tissues of the root cap. This signal results, in an unexplained way, in the production and redistribution of growth regulators, including indole-3-acetic acid and abscisic acid (ABA), which become unevenly distributed in the upper and lower parts of the root. Unequal growth rates then occur in the upper and lower sides of the zone of extension, resulting in corrective curvature. There are many reviews of geotropism (Juniper, 1976; Firn and Digby, 1980; Jackson and Barlow, 1981; Pickard, 1985) and the mechanism will not be discussed further here.

The detection of and response to gravity are rapid. The presentation time for the seedling radicle of Picea abies $L$. is only 8-10 min (Hestnes and Iversen, 1978) and curvature is often completed in a matter of hours. Orthogeotropic taproots retain their response to gravity indefinitely, although $2 \mathrm{~m}$ long roots of Quercus robur (L.) responded more slowly to displacement and had a longer radius of curvature than shorter, younger roots (Riedacker et al., 1982).

\section{Plagiogeotropic and diageotropic roots}

First order lateral roots $\left(1^{\circ} \mathrm{L}\right)$ grow from the taproot horizontally (diageotropic) or are inclined at an angle (plagiogeotropic). The angle between the lateral root and the plumb line is called the liminal angle, and is known to vary with species (Sachs, 1874). Billan et al. (1978) even found differences in the liminal angles between two provenances of Pinus taeda L.: the provenance from the driest site had the smallest angle (i.e., the most downwardly directed lateral roots). They also found that the liminal angle of the upper laterals was about twice that of those lower on the taproot, a firiding in general agreement with Sachs' (1874) observations on herbs.

The resporises of plagiotropic roots to gravity have been demonstrated by reorienting either entire plants growing in containers (Sachs, 1874; Rufelt, 1965), or individual roots (Wilson, 1971). When Wilson (1971) displaced horizontal Acer rubrum $L$. roots to angles above the horizontal, the roots bent downwards. When displaced below the horizontal, the roots did not curve, they continued to grow in the direction in which they had been placed. Such roots are described as being weakly plagiotropic (Riedacker et al., 1982). However, some species show an upward curvature of downwardly displaced roots (strong plagiotropism). In his review, Rufelt (1965) concluded that the liminal angle is determined by a balance between positive geotropism and a tendency to grow upwards, e.g., a negative geotropism.

Certain correlative effects between the tip of the taproot and the growth and orientation of $1^{\circ} \mathrm{L}$ have been described. In Theobroma cacao L., if the taproot is excised below very young laterals, some of them will bend downwards, increase in size and vigour, and become positively geotropic replacement roots, i.e., roots which replace the radicle. However, if the taproot is cut below laterals more than $7 \mathrm{~d}$ old, they do not change in growth rate or 
orientation; their behaviour has become fixed (Dynat-Nejad, 1970; Dynat-Nejad and Neville, 1972). Experiments by these workers, which included decapitation of the taproot tip and blocking its growth by coating it with plaster, showed that the progressive development of a rather stable plagiotropism by the lateral roots was related to the growth rate of the taproot, but not to that of the lateral roots themselves. Experiments on $Q$. robur indicated that the behaviour of the lateral roots in that species is determined even earlier than in T. cacao, at the primordial stage (Champagnat et al., 1974). Riedacker et al. (1982) largely confirmed this work. They found that if the tip of the taproot was blocked rather than cut, the growth of new laterals above the blockage was enhanced and they became weakly orthogeotropic. However, it took time for the roots to acquire this response and, in $Q$. suber $L$., the lateral roots grew $20-30 \mathrm{~cm}$ and developed thicker tips before turning downwards. It is not entirely clear whether such a response was also induced in lateral roots already present at the time the taproot tip was blocked.

When the tip of a main vertical or horizontal root is injured, replacement roots are free from apical dominance effects and curve forwards, to become parallel to the main root, instead of growing at the usual liminal angle, or angle with respect to the mother root (Horsley, 1971). In this way, the direction of growth of the main root axes is maintained, both outwards, away from the tree, and in the vertical plane.

The way in which the direction of root growth with respect to gravity becomes fixed, or programmed, has not been studied. Although gravity is sensed by the cap, the programme must lie elsewhere, because the cap dies when the root becomes dormant (Wilcox, 1954; John-
son-Flanagan and Owens, 1985), yet the direction of growth can remain unaltered over repeated cycles of growth and dormancy. Furthermore, loss of the entire root tip generally gives rise to replacement roots which have the same gravitropic responses as the mother root, indicating that the programme lies in the subapical portion. Work on the acquisition of the plagiogeotropic growth habit by lateral roots requires further development and extension to other species. Plagiogeotropism is even less well understood than geotropism of the radicle, on which much more work has been done, but the experiments on correlative control indicate that in the developed tree root system, it is unlikely that the vertical roots influence the orientation of existing plagiogeotropic laterals.

Lateral roots of second and higher orders of branching and diminishing diameter become successively less responsive to gravity. Since gravity is sensed by the sedimentation of the amyloplasts in the root cap, higher order roots may have caps too small to enable a geotropic response. Support for this idea comes from work on Ricinus. The first order lateral roots grow $15-20 \mathrm{~mm}$ horizontally from the taproot, then turn vertically downwards. Moore and Pasieniuk (1984) found that the development of this positive response to gravity was associated with increased size of the root cap. The gradual development of a gravitropic response in laterals of $Q$. suber might also be associated with growth of the root cap. The ectomycorrhizal roots of conifers, which are ageotropic, have poorly developed caps and the cap cells appear to be digested by the fungal partner (Clowes, 1954). Whether there are important anatomical differences between the root caps of the larger, first order plagiotropic lateral roots of trees, and the caps of taproots and sinkers, has not been determined. 


\section{The orientation of root initials}

Root orientation is determined first by the direction in which the root initial is facing before it emerges from the parent root and, subsequently, by curvature. The $1^{\circ} \mathrm{L}$ maintain a direction of growth away from the plant, an obvious advantage for soil exploration and for providing a framework for anchorage. Noll (1894) termed this growth habit of roots exotropy. The laterals are initiated in vertical files related to the position of the vascular strands in the taproot. The taproot of $Q$. robur, for example, has 4-5 strands (Champagnat et al., 1974), and the existence of 4-5 files of laterals ensures that the tree will have roots well distributed around it. In conifers, the taproot is usually triarch or tetrarch, whereas the laterals are mostly diarch, e.g., Pseudotsuga menzesii (Mirb.) Franco (Bogar and Smith, 1965), Pinus contorta (Douglas ex Louden) (Preston, 1943). In some species, the files of laterals are augmented by adventitious roots from the stem base and trees produce additional main roots by branching near the base of the $1^{\circ} \mathrm{L}$ (see Coutts, 1987).

The diarch condition of most of the lateral roots of conifers restricts branches of the next order to positions opposite the two primary xylem strands. Thus, if a line drawn through these strands in transverse section, the 'primary xylem line', is vertical, roots will emerge pointing only upwards and downwards (Fig. 1a). This vertical orientation is present in the $1^{\circ} \mathrm{L}$ at its junction with the taproot (Fig. 1b). In practice, many branches on $1^{\circ} \mathrm{L}$ at a distance from the tree are produced in the horizontal plane, as observed by Wilson (1964) in A. rubrum, therefore twisting of the root apex must occur. Wilson noted a clockwise twisting (looking away from the tree) in $A$. rubrum. Twisting is also common in Picea sitchensis (Bong.) Carr. Many roots which were sectioned showed partial rotation of the axis, followed by corrections in the opposite direction (Coutts, unpublished). Examination of 24 roots, 2-5 $\mathrm{m}$ long, showed that the primary xylem line was more commonly oriented horizontally than vertically, favouring the initiation of horizontal roots. As the root twists, the next order laterals can arise in any direction.

The angle of initiation may account for the production of sinker roots from laterals. In an unpublished study on $P$. sitchensis, sinkers were defined as roots
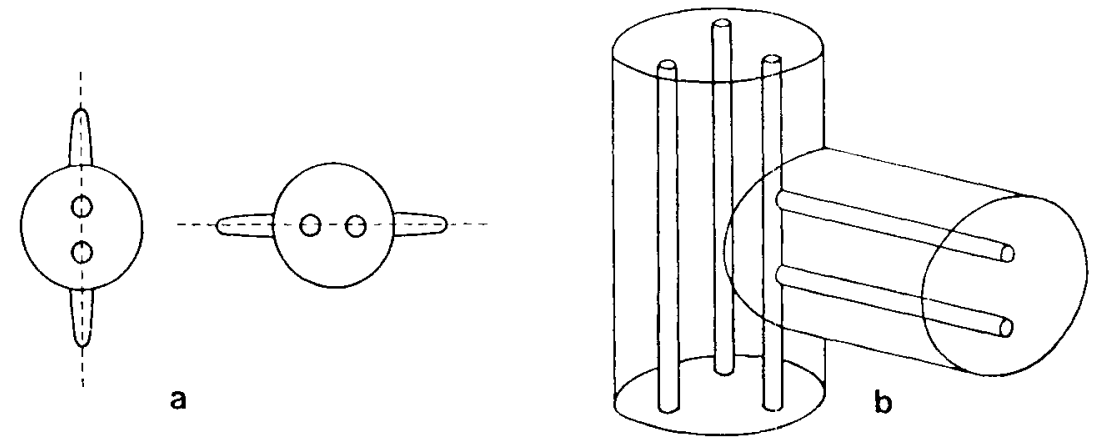

Fig. 1. a. Positions of lateral roots in relation to the primary xylem orientation and the 'primary xylem line', in a diarch conifer root. b. Origin of a lateral root on a triarch taproot, showing the original, vertical orientation of the primary xylem line on the branch. 


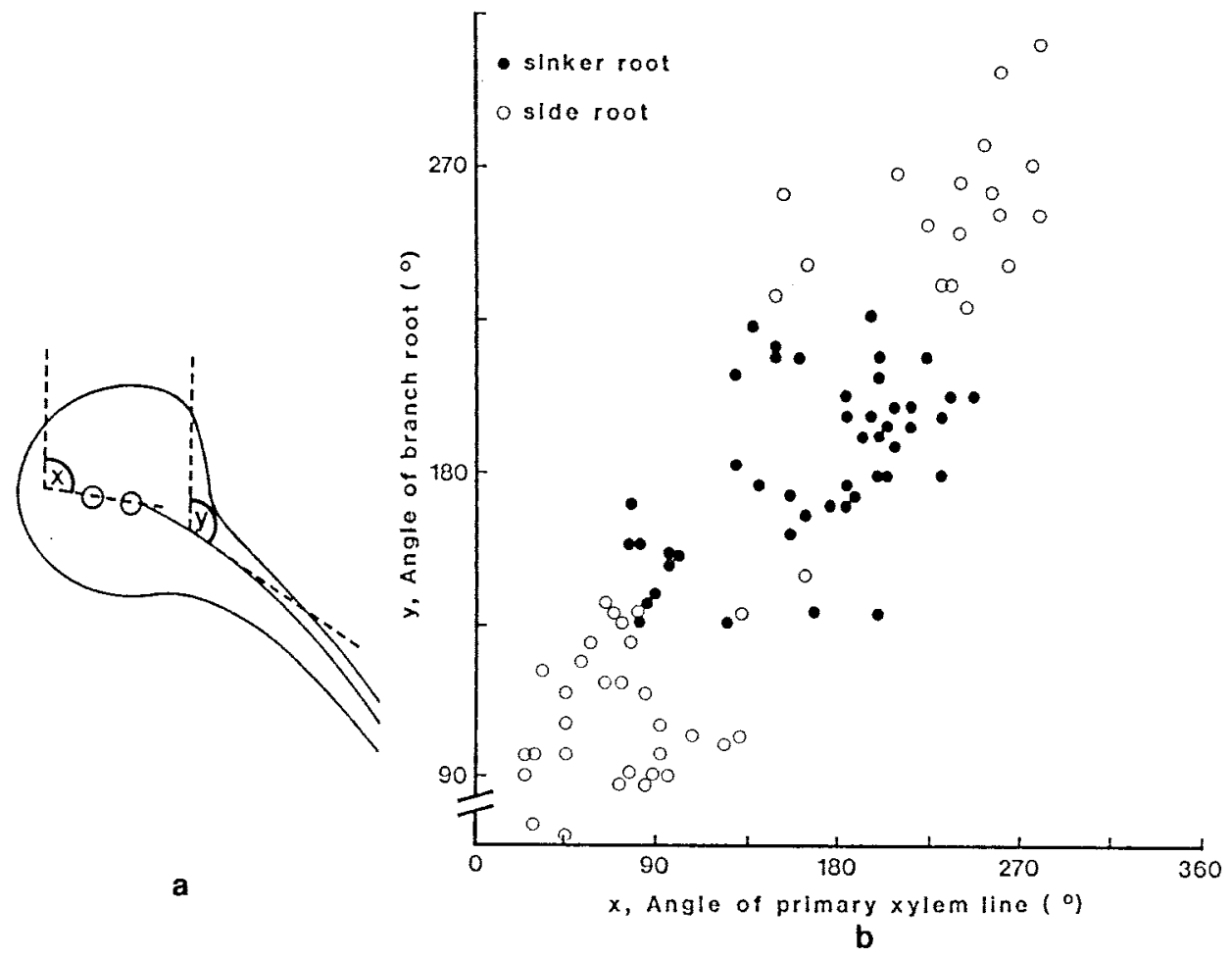

Fig. 2. Origins of sinker and side roots in $P$. sitchensis. $a$. The angle of the primary xylem line $(x)$ in the mother root, and the angle of the branch root $(y)$ measured $3.2-4.2 \mathrm{~cm}$ from the centre of the mother root. $\mathrm{b}$. Angle of primary xylem line, plotted against angle of branch root measured as shown in a. The roots were classified as sinkers or side roots depending upon their angle at a distance of $12-15 \mathrm{~cm}$ from their point of origin (see text).

growing downwards at angles of less than $45^{\circ}$ to the vertical $12-15 \mathrm{~cm}$ from their point of origin, while roots at angles within $45^{\circ}$ of the horizontal were called side roots. An examination of 50 roots of each type on $10 \mathrm{yr}$ old trees showed that the angle of growth was strongly related to the angle of initiation, and thus to the angle of the primary xylem line (Fig. 2).

Sinkers and side roots were predominantly initiated in a downward and in a horizontal direction, respectively. Roots of both types tended to curve slightly downwards after they emerged from the $1^{\circ} \mathrm{L}$. Some species, e.g., Abies, ha- ve sinker roots with a stricter vertical orientation than those of Picea, and they may therefore originate in a different way.

It is not known whether sinker roots are weakly plagiotropic, their direction being mainly a matter of the direction of initiation, or whether the tip becomes positively geotropic, perhaps by some process of habituation. Observations on Pinus resinosa Ait. indicate that the sinkers may have special geotropic properties: lateral roots from them emerge almost horizontally, but then turn sharply downwards (Fayle, 1975). 


\section{Surface roots}

Many $1^{\circ} \mathrm{L}$ curve gently downwards with distance from the tree (Stein, 1978; Eis, 1978 ), but some, which may originate from the upper part of the taproot and therefore have the largest liminal angles, grow at the soil surface, in or beneath the litter. Many surface roots are $2^{\circ} \mathrm{L}$ and $3^{\circ} \mathrm{L}$ (Lyford, 1975; Eis, 1978). Surface roots grow up steep slopes as well as downhill (McMinn, 1963). Presumably they are programmed to grow diageotropically, but their orientation is modified by the environment. The remainder of this review deals with environmental effects.

\section{Mechanical barriers}

Barriers which affect root orientation include soil layers with greater mechanical impedance than that in which the root has been growing, and impenetrable objects in the soil. Downwardly directed roots can deflect upwards to a horizontal position on encountering compacted subsoil, but turn down if they enter a crack of hole (Dexter, 1986). Horizontal roots or $A$. rubrum deflected upwards when they encountered

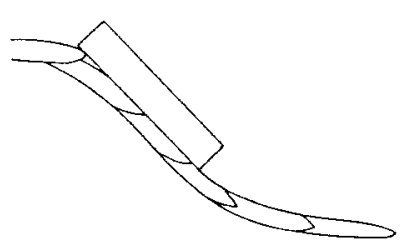

$a$

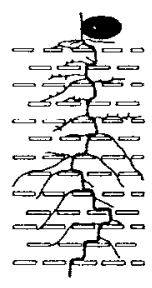

b
Fig. 3. a. Deflection of a horizontal $\boldsymbol{A}$. rubrum root at a barrier, showing temporary distortion of the root tip against the barrier (Wilson, 1967). b. Path taken by the positively geotropic taproot of $Q$. robur past $2 \mathrm{~cm}$ wide barriers in the soil (Riedacker et al., 1982). a zone of compacted vermiculite (Wilson, 1971), but roots growing downwards at $45^{\circ}$ into compacted but penetrable layers did not deflect. Wilson (1967) found that when horizontal roots of $A$. rubrum encountered vertical barriers, they deflected along them, sometimes with the root tip distorted laterally towards the barrier (Fig. 3a). On passing the barrier, the roots deflected back towards the original angle. The correction angle varied with the initial angle of incidence between root and barrier, and with barrier length. Barrier length in the range $1-7 \mathrm{~cm}$ had only a small effect on correction angle. Riedacker (1978) obtained similar results with the roots of Populus cuttings and barriers up to $7 \mathrm{~cm}$ long. With barriers $10-12 \mathrm{~cm}$ long, nearly half of the roots continued growth in the direction of the barrier. Roots made to deflect downwards at barriers inclined to the vertical, made upward corrective curvature; they were slightly less influenced by barrier length than horizontal roots. Orthogeotropic taproots of $Q$. robur seedlings deflected past a series of $2 \mathrm{~cm}$ long barriers, maintaining a remarkably vertical orientation overall (Fig. 3b). Replacement taproots formed after injury appeared to be insensitive to barrier length.

The mechanism by which roots make corrective curvatures after passing barriers is not known. Large variation in correction angles has been reported, and it is possible that barrier length is less important than the time for which the root has been forced to deflect. The mechanism is an important one for maintaining exotropic growth.

\section{Light and temperature}

Light from any' direction can increase the graviresponsiveness of the radicle and lateral roots of some herbaceous species (Lake and Slack, 1961). Light is sensed by 
the root cap (Tepfer and Bonnet, 1972). Wavelengths which elicit a response vary with plant species, e.g., Zea (Feldman and Briggs, 1987) and Convolvulus (Tepfer and Bonnett, 1972) respond to red light and show some reversal in far red, whereas the plagiotropic roots of Vanilla turn downwards only in blue light (Irvine and Freyre, 1961).

There is little information on trees. Iversen and Siegel (1976) found that when $P$. abies seedlings were lain horizontally in the light, subsequent growth of the radicle in darkness was reduced, but curvature was unaffected. Lateral roots of $P$. sitchensis showed reduced growth and downward curvature in low levels of white light (Coutts and Nicholl, unpublished). Such responses indicate that care must be exercised when using root boxes with transparent windows for studies on the direction of growth. In the field, light may help regulate the orientation of surface roots, just as it does for Aegeopodium rhizomes, which respond to a $30 \mathrm{~s}$ exposure by turning downwards into the soil (Bennet-Clark and Ball, 1951).

The growth of corn roots is influenced by temperature. At soil temperatures above and below $17^{\circ} \mathrm{C}$, plagiotropic primary roots become angled more steeply downwards (Onderdonk and Ketcheson, 1973). No information is available for trees.

\section{Waterlogging and the soil atmosphere}

Waterlogging has a drastic effect on soil aeration and consequently on tree root development (Kozlowski, 1982). Waterlogged soils are characterised by a lack of oxygen, increased levels of carbon dioxide and ethylene, together with many other chemical changes (Armstrong, 1982). The tips of growing taproots and sinkers are killed when the water table rises, and regeneration takes place when it falls during drier periods. Such periodic death and regrowth produce the well-known 'shaving brush' roots on many tree species. In spite of poor soil aeration, the tips of taproots and sinkers maintain a generally downward orientation. This could be because periods of growth coincide with periods when the soil is aerated. However, in an experiment on $P$. sitchensis grown out of doors in large containers of peat, main roots which grew down at $0-45^{\circ}$ from the vertical did not deflect when approaching a water table maintained $26 \mathrm{~cm}$ below the surface (Coutts and Nicholl, unpublished). The roots penetrated $1-5 \mathrm{~cm}$ into the waterlogged soil and then stopped growing. This behaviour contrasts with certain herbaceous species. Guhman (1924) found that the taproots and laterals of sunflower grew diageotropically in waterlogged soil, and Wiersum (1967) observed that Brassica and potato roots grew upwards towards better aerated zones. The finest roots of trees may also grow upwards from waterlogged soils, as found for Melaleuca quinquenerva (Cav.) Blake by Sena Gomes and Kozlowski (1980), and for flooded Salix (see Gill, 1970). However, the emergence of roots above flooded soil does not necessarily mean that the roots have changed direction, they may have been growing upwards prior to flooding.

Little is known about the response of plagiotropic roots to waterlogging. Armstrong and Boatman (1967) considered that the shallow horizontal root growth of Molinia in bogs was a response to waterlogged conditions, but did not present observations on growth in well-drained soil. The proliferation of the surface roots of trees on wet sites may be a result of compensatory growth rather than a change in orientation. 
The direction of growth of plant organs is influenced by $\mathrm{CO}_{2}$. For example, the diageotropic rhizomes of Aegeopodium deflect upwards in the presence of $5 \%$ $\mathrm{CO}_{2}$ (Bennet-Clark and Ball, 1951), and this response has been supposed to help maintain their position near the soil surface. Ycas and Zobel (1983) measured the deflection of the plagiotropic radicle of corn exposed to various concentrations of $\mathrm{O}_{2}, \mathrm{CO}_{2}$ and ethylene. Substantial effects on the direction of growth were obtained only with $\mathrm{CO}_{2}$. Roots in normal air grew at an angle of $49^{\circ}$ to the vertical, whereas in $11 \% \mathrm{CO}_{2}$ they deflected upwards to an angle of $72^{\circ}$. The minimum concentration of $\mathrm{CO}_{2}$ required to cause measurable deflection was $2 \%$. Concentrations of $2-11 \% \mathrm{CO}_{2}$ are above those found in welldrained soils but, in poorly draining, forested soils, Pyatt and Smith (1983) frequently found $5-10 \% \mathrm{CO}_{2}$ at depths of $35-50 \mathrm{~cm}$. However, concentrations were usually less than $5 \%$ at a depth of $20 \mathrm{~cm}$ and would presumably have been lower still nearer the surface, where most of the roots were present. In Ycas and Zobel's (1983) experiments, ethylene at non-toxic concentrations had little effect on the direction of corn root growth, and only small effects on corn had been found by Bucher and Pilet (1982). In another study, orthogeotropic pea roots responded to ethylene by becoming diageotropic but the roots of three other species did not respond in this way (Goeschl and Kays, 1975).

It appears as though the downwardly growing roots of trees do not deflect on encountering waterlogged soil. This failure to deflect is consistent with the conclusion of Riedacker et al. (1982) that the positive geotropism of tree roots is difficult to alter. There is not enough information on plagiogeotropic roots to say whether soil aeration affects their orientation.

\section{Dessication}

The curvature of roots towards moisture is called hydrotropism. Little work has been done on it and Rufelt (1969) questioned whether the phenomenon exists. Sachs (1872) grew various species in a sieve of moist peat, hanging inclined at an angle in a dark cupboard. When the seedling roots emerged into water-saturated air, they grew downwards at normal angles, but in drier air they curved up through the smallest angle towards the moist surface of the peat. Sachs concluded that they were responding to a humidity gradient. Loomis and Ewan (1935) tested 29 genera, including Pinus, by germinating seeds between layers of wet and dry soil held in various orientations. In most plants tested, including Pinus, no consistent curvature towards the wet soil occurred. In species which gave a positive result, the $1^{\circ} \mathrm{L}$ were unaffected, only the radicle responded. Some of the non-responsive species had responded in Sachs' system, an anomaly which may be explained by problems of methodology. The containers of wet and dry soils in Loomis and Ewan's experiments were placed in a moist chamber and the vapour pressure of the soil atmosphere may well have equilibrated during the course of the experiment.

Jaffe et al. (1985) studied hydrotropism in the pea mutant, 'Ageotropum', which has roots not normally responsive to gravity. Upwardly growing roots which emerged from the soil surface continued to grow upwards in a saturated atmosphere but, at relative humiclities of $75-82 \%$, they bent downwards to the soil. No response took place if the root cap was removed and it was concluded that the cap sensed a humidity gradient.

These results have implications for the behaviour of tree roots at the soil surface and where horizontally growing roots 
encounter the sides of drains. For example, when $P$. sitchensis roots grow from the side of a furrow made by spacedfurrow ploughing, they turn downwards on emerging into litter or overarching vegetation. Experiments to investigate this behaviour shewed that horizontal roots which emerged from moist peat into air at a relative humidity of $99 \%$ grew without deflecting, but at $95 \%$ they deflected downwards to the peat (Coutts and Nicholl, unpublished). This behaviour could have been a hydrotropic response, but roots which grew out from the peat at angles above the horizontal into air at $95 \%$ humidity, also turned downwards, rather than upwards towards the nearest moist surface. This suggests that localised water stress at the root tip had induced a positive geotropic response. It is relevant to note that water stress induces the formation of ABA in root tips (Lachno and Baker, 1986; Zhang and Davies, 1987), and ABA has been implicated in geotropism. An explanation of geotropism induced by water stress could also apply to the downward curvature of otherwise ageotropic roots already mentioned, but not to upward curvatures in Sachs' experiments. It is in any case unlikely that roots growing in soil exhibit hydrotropism because the vapour pressure difference, even between moist soil and soil too dry to support root growth, is so small (Marshall and Holmes, 1979) that roots would be unlikely to detect it. A positive geotropic response by roots in diry soil would be likely to direct them to moister layers lower down.

\section{Conclusions}

The seedling radicle, and roots which replace it after injury, are usually positively geotropic. Sinker roots, at least in one species, appear to originate from root primordia which happen to be angled downwards. Their georesponsiveness is unknown. The gravitropism of taproots is a stable feature and the vertical roots of trees do not seem to deflect from waterlogged soil layers, unlike the roots of certain herbs. They have been made to deflect only on encountering impenetrable barriers.

The direction of growth of first order laterals around the tree in the horizontal plane is set by the position of the initials on the taproot. The direction of growth is maintained away from the tree by corrective curvatures, when the root is made to deflect by obstacles in the soil. If the tip is killed, replacement roots also curve and continue growth in the direction of the main axis. In the vertical plane, geotropic responses of the laterals are subject for a short period to correlative control by the tip of the taproot. Work on broadleaved species indicates that during that period, the lateral root apex becomes programmed to grow at a particular angle to the vertical. This angle can be modified by the environment: temperature, light and humidity can alter the graviresponsiveness of lateral roots. It is not certain whether hydrotropic responses occur nor whether the lateral roots of trees respond to soil aeration or deflect from waterlogged soil. The way in which the growth of main lateral roots is maintained near the soil surface, even in roots growing uphill, is not properly understood. Thin roots of more than first order, including mycorrhizas, have small roots caps and do not appear to respond to gravity.

\section{Acknowledgment}

I thank Dr. J.J. Philipson for his helpful comments on the manuscript. 


\section{References}

Armstrong W. (1982) Waterlogged soils. in: Environment and Plant Ecology (Etherington J.R., ed.), John Wiley, Chichester, pp. 290-330

Armstrong W. \& Boatman D.J. (1967) Some field observations relating the growth of bog plants to conditions of soil aeration. J. Ecol. 55, $101-110$

Bennet-Clark T.A. \& Ball N.G. (1951) The diageotropic behaviour of rhizomes. J. Exp. Bot. 2, 169-203

Bilan M.V., Leach J.H. \& Davies G. (1978) Root development in loblolly pine (Pinus taeda L.) from two Texas seed sources. In: Root Form of Planted Trees (van Eerden E. \& Kinghorn J.M., eds.), British Columbia Ministry of Forests/Canadian Forestry Service, Joint Report no. 8, pp. 17-22

Bogar G.D. \& Smith F.H. (1965) Anatomy of seedling roots of Pseudotsuga menziesii. Am. J. Bot. 52, 720-729

Bucher D. \& Pilet P. (1982) Ethylene effects on growing and gravireacting maize root segments. Physiol. Plant. 55, 1-4

Champagnat M., Baba J. \& Delaunay M. (1974) Corrélations entre le pivot et ses ramifications dans le système racinaire de jeunes chênes cultivés sous un brouillard nutritif. Rev. Cytol. Biol. Vég. 37, 407-418

Clowes F.A.L. (1954) The root cap of ectotrophic mycorrhizas. New Phytol. 53, 525-529

Coutts M.P. (1987) Developmental processes in tree root systems. Can. J. For. Res. 17, 761767

Dexter A.R. (1986) Model experiments on the behaviour of roots at the interface between a tilled seed-bed and a compacted sub-soil. Plant Soil 95, 149-161

Dynat-Nejad H. (1970) Contrôle de la plagiotropie des racines latérales chez Theobroma cacao L. Bull. Soc. Bot. Fr. 117, 183-192

Dynat-Nejad H. \& Neville P. (1972) Sur le mode d'action du méristème radical orthotrope sur le contrôle de la plagiotropie des racines latérales chez Theobroma cacao L. Rev. Gen. Bot. 79, 319-340

Eis S. (1978) Natural root forms of western conifers. In: Root Form of Planted Trees (van Eerden E. \& Kinghorn J.M., eds.), British Columbia Ministry of Forests/Canadian Forestry Service, Joint Report no. 8, pp. 23-27

Fayle D.C.F. (1975) Extension and longitudinal growth during the development of red pine root systems. Can. J. For. Res. 5, 109-121
Feldman L.J. \& Eiriggs W.R. (1987) Light-regulated gravitropism in seedling roots of maize. Plant Physiol. 53, 241-243

Firn R.D. \& Digby J. (1980) The establishment of tropic curvatures in plants. Annu. Rev. Plant Physiol. 31, 131-148

Gill C.J. (1970) The flooding tolerance of woody species - a review. For. Abstr. 31, 671-688

Goeschl J.D. \& Kays S.J. (1975) Concentration dependencies of some effects of ethylene on etiolated pea, peanut, bean and cotton seedlings. Plant Physiol. 55, 670-677

Guhman H. (1924) Variations in the root system of the common everlasting (Gnaphalium polycephalum). Ohio J. Sci. 24, 199-208

Hestnes A. \& Iversen T. (1978) Movement of cell organelles and the geotropic curvature in roots of Norway spruce (Picea abies). Physiol. Plant. 42, 406-414

Horsley S.B. (1971) Root tip injury and development of the paper birch root system. For. Sci. $17,341-348$

Irvine J.E. \& Freyre R.H. (1961) Diageotropism in Vanilla roots. Science 134, 56-57

Iversen T. \& Siege! K. (1976) The geotropic curvature in roots of Norway spruce (Picea abies) containing anthocyanins. Physiol. Plant. 37, 283-287

Jackson M.B. \& Elarlow P.W. (1981) Root geotropism and the role of growth regulators from the cap: a re-examination. Plant Cell Environ. 4, 107-123

Jaffe M.J., Takahashi H. \& Biro R.L. (1985) A pea mutant for the study of hydrotropism in roots. Science 230, 445-447

Johnson-Flanagan A.M. \& Owens J.N. (1985) Development of white spruce (Picea glauca) seedling roots. Can. J. Bot. 63, 456-462

Juniper B.E. (1976) Geotropism. Annu. Rev. Plant Physiol. 27, 385-406

Karizumi N. (1957) Studies on the form and distribution habit of the tree root. Bull. For. Exp. Sta. Meguro, Tokyo no. 94, pp. 205 (in Japanese)

Kozlowski T.T. (1982) Water supply and tree growth. Part 2, Flooding. For. Abstr. 43, 145161

Lachno D.R. \& Baker D.A. (1986) Stress induction of abscisic acid in maize roots. Physiol. Plant. 68, 215-221

Lake J.V. \& Slack G. (1961) Dependence on light of geotropism in plant roots. Nature 191, 300-302 
Loomis W.E. \& Ewan L.M. (1935) Hydrotropic responses of roots in soil. Bot. Gaz. 97, 728743

Lyford W.H. (1975) Rhizography of non-woody roots of trees in the forest floor. In: The Development and Function of Roots. (Torrey J.G. \& Clarkson D.T., eds.), Academic Press, London, pp. 179-196

Marshall J.J. \& Holmes J.W. (1979) In: Soil Physics. Cambridge University Press, Cambridge, pp. 345

McMinn R.G. (1963) Characteristics of Douglas fir root systems. Can. J. Bot. 41, 105-122

Mitchell R.L. \& Russell W.J. (1971) Root development and rooting patterns of soybean (Glycine $\max$ (L.) Merill) evaluated under field conditions. Agron. J. 64, 313-316

Moore R. \& Pasieniuk J. (1984) Graviresponsiveness and cap dimensions of primary and secondary roots of Ricinus communis (Euphorbiaceae). Can. J. Bot. 62, 1767-1769

Noll F. (1894) Ueber eine neue eigenschaft des wurzelsystems. In: Sitzungsbericht Niederrheinschen Gesellschaft Fur Natur-und Heilkunde. Springer-Verlag, Bonn, pp. 34-36

Onderdonk J.J. \& Ketcheson J.W. (1973) Effect of soil temperature on direction of corn root growth. Plant Soil 37, 177-186

Pickard B.G. (1985) Roles of hormones, protons and calcium in geotropism. In: Encyclo pedia of Plant Physiology, New Series, 2 (Pirson A. \& Zimmermann M.H., eds.), SpringerVerlag, Berlin, pp. 193-265

Preston R.J. (1943) Anatomical studies of the root of juvenile lodgepole pine. Bot. Gaz. 104, 443-448

Pyatt D.G. \& Smith K.A. (1983) Water and oxygen regimes of four soil types at Newcastleton Forest, south Scotland. J. Soil Sci. 34, 465-482

Raper C.D. \& Barber S.A. (1970) Rooting systems of soybeans. I. Differences in root morphology among varieties. Agron. J. 62, 581-584

Riedacker A. (1978) Etude de la déviation des racines horizontales ou obliques issues de boutures de peuplier qui rencontre un obstacle: applications pour la conception de conteneurs. Ann. Sci. For. 35, 1-18

Riedacker A., Dexheimer J., Tavakol R. \& Alaoui H. (1982) Modifications expérimentales de la morphogénèse et des géotropismes dans le système racinaire de jeunes chênes. Can. J. Bot. 60, 765-778
Rufelt H. (1965) Plagiogeotropism in roots. In: Encyclopedia of Plant Physiology, 17. (Ruhland W., ed.), Springer, Berlin, pp. 322-343

Rufert H. (1969) Geo- and hydrotropic responses of roots. In: Root Growth. (Whittington W.J., ed.), Butterworths, London, pp. 54-64

Sachs J. (1872) Ablenkung der wurzeln von ihrer normalen wachsthumsrichtung durch feuchte korper. Arb. Bot. Inst. Wurzburg 1, 209222

Sachs J. (1874) Ueber das wachsthum der haupt-und nebenwurzeln. Arb. Bot. Inst. Wurzburg 1, 584-634

Sena Gomes A.R. \& Kozlowski T.T. (1980) Responses of Melaleuca quinquenervia seedlings to flooding. Physiol. Plant. 49, 373-377

Stein W.I. (1978) Naturally developing seeding roots of five western conifers. In: Root Form of Planted Trees. (van Eerden E. \& Kinghorn J.M., eds.), British Columbia Ministry of Forests/ Canadian Forestry Service, Joint Report no. 8, pp. 28-35

Strong W.L. \& La Roi G.H. (1983) Root system morphology of common boreal forest trees in Alberta, Canada. Can. J. For. Res. 13, 11641173

Tepfer D.A. \& Bonnett H.T. (1972) The role of phytochrome in the geotropic behaviour of roots of Convolvulus arvensis. Planta 106, 311-324

Wiersum L.K. (1967) Presumed aerotropic growth of roots of certain species. Naturwissenschaften $8,203-204$

Wilcox $H$. (1954) Primary organization of active and dormant roots of noble fir, Abies procera. Am. J. Bot. 41, 812-821

Wilkins M.B. (1975) The role of the root cap in geotropism. Curr. Adv. Plant Sci. 6, 317-328

Wilson B.F. (1964) Structure and growth of woody roots of Acer rubrum L. Harv. For. Pap. 11, pp. 14

Wilson B.F. (1967) Root growth around barriers. Bot. Gaz. 128, 79-82

Wilson B.F. (1971) Vertical orientation of red maple (Acer rubrum L.) roots. Can. J. For. Res. 1, 147-150

Ycas J.W. \& Zobel R.W. (1983) The response of maize radicle orientation to soil solution and soil atmosphere. Plant Soil 70 , 27-35

Zhang J. \& Davies W.J. (1987) Increased synthesis of $A B A$ in partially dehydrated root tips and $A B A$ transport from roots to leaves. J. Exp. Bot. 38, 2015-2023 